\title{
Splenik Hamartom: Olgu Sunumu
}

\section{Splenic Hamartoma: Case Report}

\section{Leymune PARLAK ${ }^{1}$, Nazan BOZDOĞAN ${ }^{2}$, Ahmet Sait ÇELEBİOĞLU ${ }^{3}$}

\author{
${ }^{1}$ Uzm. Dr. Sağlik Bilimleri Üniversitesi, Mehmet Akif İnan Eğitim ve Araştırma Hastanesi, Patoloji Kliniği, ŞANLIURFA \\ ${ }^{2}$ Doç. Dr. Sağlık Bilimleri Üniversitesi, Abdurrahman Yurtarslan Ankara Onkoloji Eğitim ve Araştırma Hastanesi, Patoloji Kliniği, ANKARA \\ ${ }^{3}$ Uzm. Dr. Sağlık Bilimleri Üniversitesi, Abdurrahman Yurtarslan Ankara Onkoloji Eğitim ve Araştırma Hastanesi, Genel Cerrahi Kliniği, \\ ANKARA
}

\section{$\ddot{O ̈ z}$}

Splenik hamartom (Splenoma) normal dalak elemanlarının anormal yerleşimiyle karakterize dalağın nadir benign malformasyonudur. Genellikle asemptomatiktir. Otopsilerde ya da splenektomilerde insidental olarak saptanır. Nadiren trombositopeni, splenomegali ve anemi gibi semptomlar oluşturabilir.

Karın ağrısı ile başvuran 48 yaşındaki hastaya MR'de kitle saptanması üzerine splenektomi uygulandı.Hematoksilen eozin boyamasında normal dalak dokusundan iyi sınırlarla ayrılan ancak belirgin kapsül yapısına sahip olmayan lezyon görülmüştür. Bu lezyon kırmızı pulpa özelliğinde olup beyaz pulpaya ait eleman görülmemiştir. $\mathrm{Bu}$ lezyon kırmızı pulpa özelliğinde olup beyaz pulpaya ait eleman görülmemiştir. Lezyonda endotel hücreleri ile döşeli çok sayıda damar yapısı, histiosit ve az sayıda lenfosit izlenmiştir. Yer yer kanama alanları ve az sayıda hemosiderin yüklü makrofaj görülmüştür. Yapılan immünohistokimyasal boyamalarda; damar yapılarında CD34 ve CD31 ile yaygın boyanma izlenirken CD8 ile fokal boyanma görülmüştür. CD3 ve CD20 ile lenfoid hücrelerde, CD68 ile histiositlerde pozitif boyanma olmuştur. PanCK, S100, CD1a ile boyanma olmamıştır. Olguya splenik hamartom tanısı verilmiştir. Olgu, splenik hamartomun nadir olması ve ayırıcı tanıda akılda tutulması gerekliliği için sunulmuştur

Anahtar Kelimeler: Hamartom, dalak, kitle, splenoma

\section{Abstract}

Splenic hamartoma (Splenoma) is a rare benign malformation of the spleen characterized by the abnormal placement of normal spleen elements. It is usually asymptomatic and incidentally detected in splenectomies and autopsy. Rarely, it can cause symptoms such as thrombocytopenia, splenomegaly and anemia.

A 48-year-old patient referred to the hospital with abdominal pain. Abdominal MR revealed a mass in the spleen. The patient underwent splenectomy. Hematoxylin-eosin staining revealed a lesion that was well separated from normal spleen tissue but did not have a clear capsule structure. This lesion was red pulp and no white pulp elements were seen. In the lesion, a small number of lymphocytes and hemosiderin-loaded macrophages, histiocytes, numerous vascular structures with endothelial cells, bleeding sites were observed. Immunohistochemical stainings made; extensive staining with CD34, CD31 and focal staining with CD8 was observed in vascular structures.CD3, CD20 (lymphoid cells), CD68 (histiocytes) were positive and PanCK, S100, CD1a were negative. It was diagnosed as splenic hamartoma. The case is presented because splenic hamartomas are rare and should be kept in mind in differential diagnosis.

Key Words: Hamartoma, spleen, mass, splenoma

\section{GİRIŞ}

Hamartom dalağın nadir görülen benign lezyonudur (1). Genellikle asemptomatik olup otopsilerde ya da farklı nedenlerle yapılan splenektomilerde insidental olarak saptanır. Nadiren de splenomegali, trombositopeni ve anemi gibi semptomlar gösterebilirler $(2,3)$.

\section{OLGU SUNUMU}

48 yaşındaki erkek hasta hastaneye karın ağrısı şikayeti ile başvurmuştur. Çekilen MR'de dalakta kitle saptanması üzerine splenektomi uygulanmıştır.

Makroskopide splenektomi materyalinde $6 \times 5,5 \times 5 \mathrm{~cm}$ ölçülerinde dalak ile sınırları net seçilemeyen kitle görülmüştür.

Mikroskopik incelemede Hematoksilen\&Eozin boyası ile normal dalak dokusundan iyi sinırla ayrılan ancak belirgin kapsül yapısına sahip olmayan lezyon görülmüştür (Resim1). $\mathrm{Bu}$ lezyon kırmızı pulpa özelliğinde olup beyaz pulpaya ait eleman görülmemiştir. Lezyonda endotel hücreleri ile döşeli çok

Bu çalışma 24. Ulusal Patoloji kongresi,

İletişim: $\begin{aligned} & \text { Dr. Leymune Parlak, Mehmet Akif İnan Eğitim ve } \\ & \text { Araştırma Hastanesi, Patoloji Kliniği, Şanlıurfa }\end{aligned}$
DOI:
$\quad \mathbf{1 0 . 1 7 5 1 7 / k s u t f d . ~} \mathbf{4 4 2 7 0 5}$

sayıda damar yapısı, histiyosit ve az sayıda lenfosit izlenmiștir (Resim 2). Yer yer kanama alanları ve az sayıda hemosiderin yüklü makrofaj görülmüştür. Yapılan immünhistokimyasal incelemede; damar yapilarında CD34 ve CD31 ile yaygın boyanma izlenirken (Resim 3) CD8 ile fokal boyanma görülmüştür (Resim 4). CD3 ve CD20 ile lenfoid hücrelerde, CD68 ile az sayıdaki histiyositlerde pozitif boyanma olmuştur. PanCK, S100, CD1a ile boyanma olmamıştır.

\section{TARTIŞMA}

Splenik hamartom ilk kez 1861'de Rokitansky tarafından tanımlanan ve splenoma olarak adlandırılan dalağın nadir görülen benign lezyonudur (3). Otopsilerde insidansı \% 0,13'dür. Splenektomilerde ise insidans 3/200.000'de olarak rapor edilmiştir. Genellikle asemptomatik olmakla birlikte hematolojik hastalıklarla ilişkili olarak anemi, pansitopeni, trombositopeni gibi semptomlar da görülebilir. Literatürde

\section{Trabzon'da poster olarak sunulmuştur.}

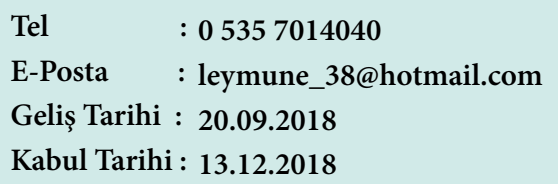


Resim 1: Normal dalak dokusundan iyi sinırla ayrilan kapsülsüzlezyon (H\&E x100)

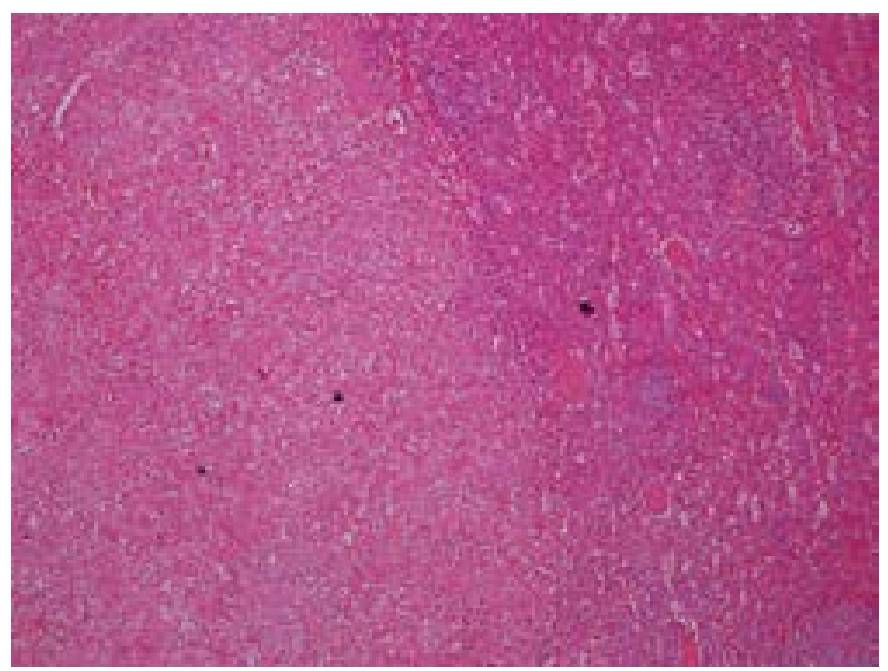

Resim 2: Kırmızı pulpa özelliğindeki lezyonda endotel hücreleri ile döşeli çok sayıda damar yapısı, histiyosit ve az sayıda lenfosit (H\&E x400)

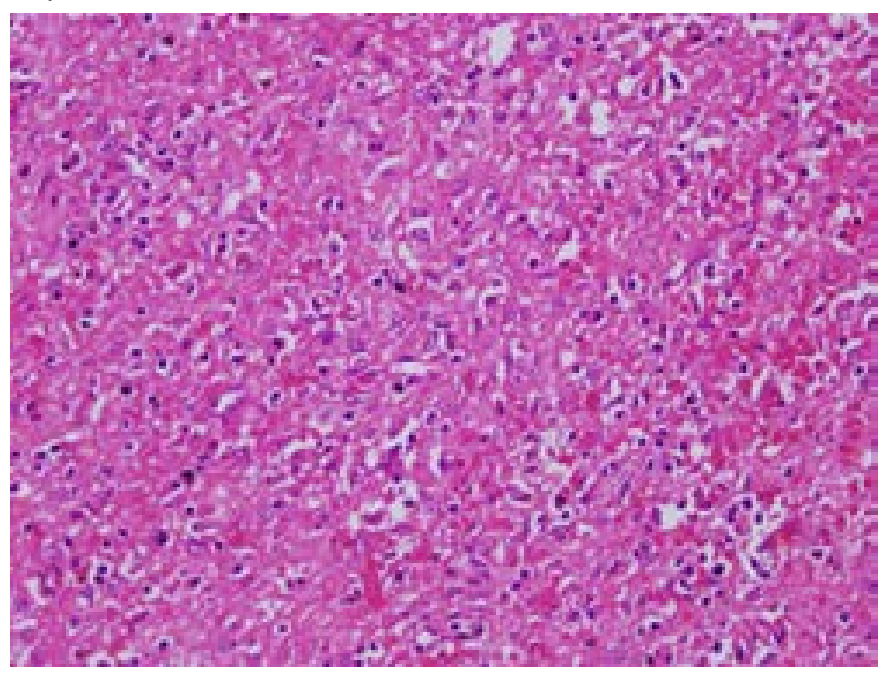

Resim 3: CD31 ile damar endotellerinde yaygin boyanma (İHK x400)

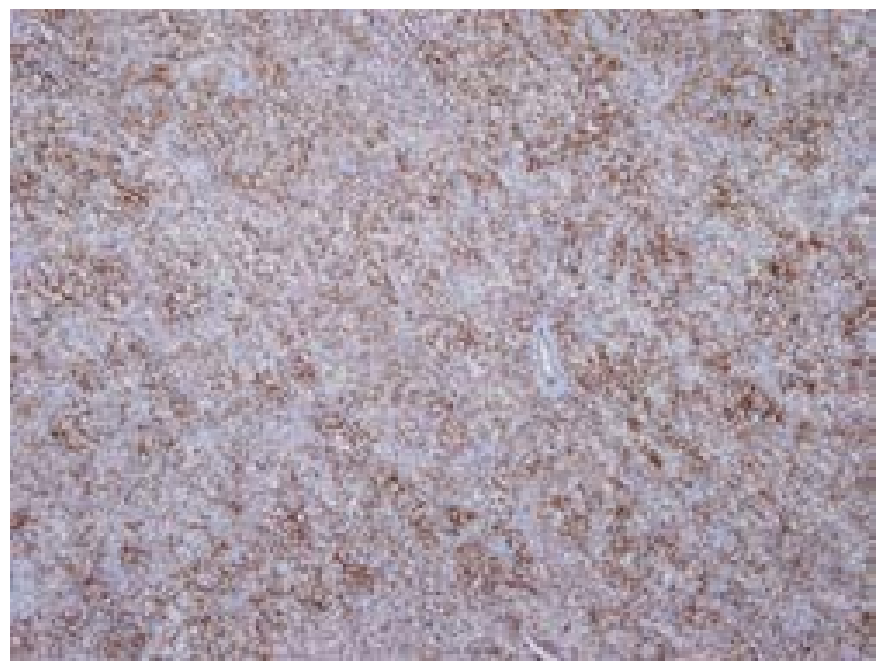

bildirilen vakaların \% 20'si çocuktur (4). Çocukluk dönemi vakaları daha çok semptomatik olarak karşımıza çıkmaktadır. Ayrıca hipersplenizm, tüberoskleroz ve Wiskott-Aldrich
Resim 4: CD8 ile fokal boyanma (İHK x400)

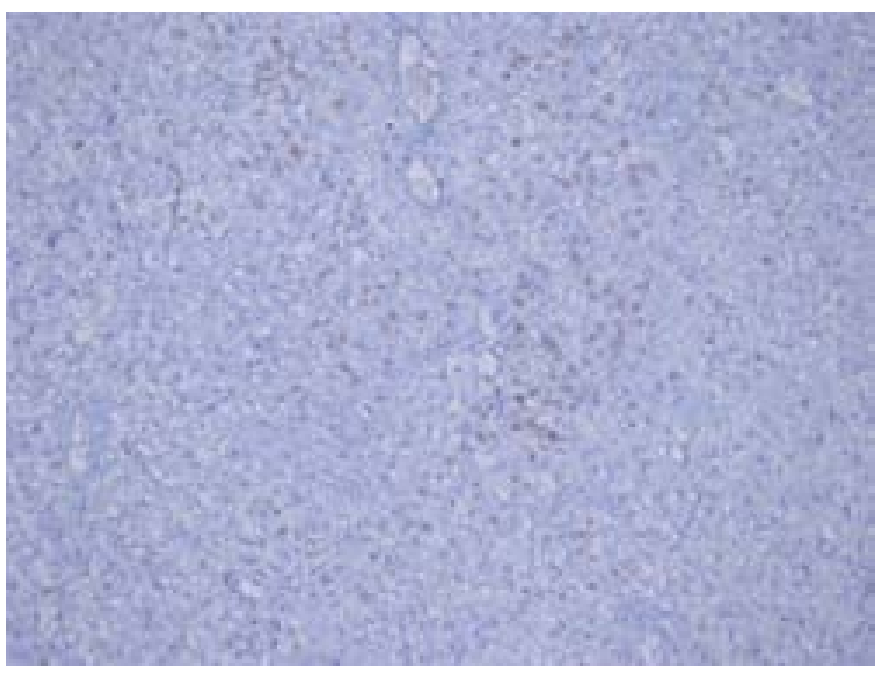

sendromu ile ilişkili vakalar bildirilmiștir (5). Bizim olgumuz da; hasta hematolojik bulgular olmaksızın karın ağrısı ile hastaneye başvurmuştu.

Splenik hamartomlar genellikle multiple veya tek, yuvarlak iyi sınırlı, enkapsüle, çevre komşu parankimi basıya uğratan koyu kırmızı nodüler lezyonlardır. Boyutu birkaç milimetreden 20 santimetreye kadar değişebilir (6). İnfiltrasyon olmaksızın iyi sınırlı splenik parankime bası yapan tek veya multiple olabilen, solid nodüler lezyon şeklinde izlenir. Yaygın olarak kırmızı pulpa elemanlarının anormal yerleșimiyle karakterizedir. Lezyon düzensiz yarıklar, tübüller, ektatik veya kavernöz şişkin endotel hücreleri ile döşeli vasküler kanallar içerir (7). Bu lezyonlarda follikül yapıları ve dendritik hücreler gözlenmez. Fibröz trabeküller nadirdir (8). Vasküler kanalları döşeyen bu hücreler tipik olarak CD8, CD31, CD34, Faktör VIII-relatedAg ve Vimentin ile pozitiftir (1). Bizim olgumuzda da gözlediğimiz CD 8 pozitifliği hamartomlarda önemli tanısal bir bulgudur.

Splenik hamartomile ayırıcı tanıya öncelikle hemanjiom, littoral hücreli anjiom, lenfanjiom, hemanjioendotelyoma, sklerozan anjiomatoid nodüler transformasyon ve anjiosarkom girmektedir. Hemanjiom; ince fibröz septalar veya kırmızı pulpa ile döşeli vasküler boşluklardan oluşmaktadır. Benign gidiş gösterir ancak rüptüre olabilir. Hemanjiomlar CD31 ve CD34 pozitif, CD8 negatiftir (9). Littoral hücreli anjiom; splenomegali yapan, biyolojik davranışı bilinmeyen genellikle papiller uzanımlar oluşturmuş anastomozlaşan kolumnar hücreler ile döşeli vasküler kanallar ile karakterizedir. Döșeyici epitelde makrofaj belirleyicileri olan CD68 ve lizozomun her ikisinin co-expresyonu karakteristiktir (10). Lenfanjiom; değişik büyüklüklerde içinde proteinöz sıvı içeren kistik boşlukları basık endotelyal hücrelerin döșediği lezyondur. CD8 negatif, CD31 pozitiftir $(9,11)$. Hemanjioendotelyoma; hafif veya orta dereceli atipik hücreler ile döșeli vasküler kanallardır. CD31 ve Faktör VIII related Ag pozitifken, CD34 değişken oranda pozitif boyanır. Sklerozan anjiomatoid nodüler transformasyon; konsantrik fibröz rim tarafından çevrelenmiş multiple konfluent nodülden oluşan benign lezyondur. Sinüzoidler CD34 negatif, CD31 ve CD8 pozitif; kapillerler: CD34ve CD31 pozitif, CD8 negatif, küçük venler CD31 pozitif, CD31ve CD8 negatiftir. Anjiosarkom ise; oldukça atipik hücreler ile döşeli anastomozlaşan vasküler kanallardan oluşan malign lezyondur. CD31, CD34, FaktörVIIIa ve CD68 pozitiftir (9). 
Özelllikle tanı zorluğu çekilen bizar hücreli splenik hamartom gibi dalağın solid lezyonlarının ayırıcı tanısında ise inflamatuar myofibroblastik tümör (İMT), folliküler dentritik hücreli sarkom (FTHS), anjiosarkom, Hogdkin Lenfoma düşünülmelidir. $(6,12)$. İMT lenfosit, eozinofil ve plazma hücrelerinden oluşan zeminde iğsi myofibroblastik hücrelerden oluşur. CD8 ve CD31 negatiftir. FTHS lenfoplazmasitik hücrelerden baskın infiltrasyona sahip iğsi ve ovoid hücreli neoplastik bir proliferasyondur. Splenik hamartomun aksine folliküler dentritik hücre markerları (CD21, CD23, CD35 ) pozitiftir. Büyük çift nukleuslu, stromal hücrelerin varlığı Reed Strenberg hücrelerini hatırlatması nedeniyle Hodgkin Lenfoma ile ayırıcı tanı gerektirir (6).

Sonuç olarak, splenik hamartom dalakta kitle oluşturan diğer lezyonlar ve malignitelerden ayrımda önemli ve akılda tutulması gereken bir antitedir.

\section{KAYNAKLAR}

1. Sim J, Ahn HI, Han H, Jun YJ, Rehman A, Jang SM, et al. Splenic hamartoma: A case report and review of the literature. World J Clin Cases 2013; 1: 217-9

2. Jia HB, Li YP, Han DE, Liu Y, Zhang B, Wu DQ, et al. Splenic hamartoma: case report and review of literature. Chin Med J (Engl). 2006; 119: 1403-8. Review.

3. Tsitouridis I, Michaelide SM, Tsitouridis K, Davidis I, Efstratiou I. Symptomatic splenoma (hamartoma) of the spleen. A case report. Hippokratia. 2010; 14: 54-6

4. Afşarlar ÇE, Özen İO, Demiroğulları B, Sönmez K, Moralığlu S, Poyraz A ve ark. Symptomatic splenic hamar- toma: A case treated with partial splenectomy and review of the literature. Turkiye Klinikleri J Med Sci 2009; 29: 1720-3

5. Giambelluca D, Picone D, Re GL, Pappalardo S, Romeo P. Hamartoma of the spleen (splenoma) with calcifications in a child with beta-thalassemia: A case report. J Radiol Case Rep; 11: 712.

6. Cheng N, Chen J, Pan Y, Jiang Y, Zhou J, Shao C. Splenic hamartoma with bizarre stromal cells: a case report and literature review. Diagn Pathol. 2018; 13: 8.

7. Nalbant OA, Neşe N, Kahya M, İşisağ A. Splenik Hamartom. Türk Patoloji Dergisi 2009; 25: 122-5

8. Juan R. Spleen. In: Juan R, ed. Rosai and Ackerman's Surgical Pathology, 10th edition, St Louis, Elsevier,2011. P. 1901-25

9. Hwajeong L, Koichi M. Hamartoma of the spleen. Arch Pathol Lab Med 2009; 133: 147-51

10. Du J, Shen Q, Yin H, Zhou X, Wu B. Littoral cell angioma of the spleen: report of three cases and literature review. Int J Clin Exp Pathol. 2015; 8: 8516-20.

11. Yang F, Chen WX. Splenic lymphangioma that manifested as a solid-cystic mass: a case report. World J Gastroenterol. 2013; 19: 7849-51.

12. Komo T, Hihara J, Kanou M, Kohashi T, Ohmori I, Yoshimitsu M, et al. Splenic hamartoma associated with thrombocytopenia: A case report. Int J Surg Case Rep 2017; 39: $172-5$. 